\title{
The capability of minor quaternary benzophenanthridine alkaloids to inhibit TNF- $\alpha$ secretion and cyclooxygenase activity
}

\author{
Jan Hošek ${ }^{1}$, Kristýna Šebrlová2 ${ }^{2}$ Petra Kaucká ${ }^{3}$ Ondřej Peš², Eva Táborská ${ }^{2}$ \\ ${ }^{1}$ University of Veterinary and Pharmaceutical Sciences Brno, Faculty of Pharmacy, \\ Department of Molecular Biology and Pharmaceutical Biotechnology, Brno, Czech Republic \\ ${ }^{2}$ Masaryk University, Faculty of Medicine, Department of Biochemistry, Brno, Czech Republic \\ ${ }^{3}$ University of Veterinary and Pharmaceutical Sciences Brno, Faculty of Pharmacy, \\ Department of Natural Drugs, Brno, Czech Republic \\ Received January 27, 2017 \\ Accepted May 31, 2017
}

\begin{abstract}
Quaternary benzophenanthridine alkaloids are known to have a wide range of biological effects, including antimicrobial, antifungal, anti-inflammatory, and antitumour activities. However, only sanguinarine and chelerythrine have been studied intensively. The aim of this study was to evaluate the anti-inflammatory potential of the five minor quaternary benzophenanthridine alkaloids sanguilutine, sanguirubine, chelirubine, chelilutine, and macarpine in vitro and to compare them with more thoroughly studied sanguinarine and chelerythrine. Before making cellbased assays, the cytotoxicity of the alkaloids was evaluated. The anti-inflammatory potential of the chosen alkaloids was evaluated as for their ability to modulate the lipopolysaccharideinduced secretion of tumour necrosis factor $\alpha(\mathrm{TNF}-\alpha)$ in the macrophage-like cell line THP-1. The cyclooxygenase (COX)-1 and COX-2 inhibitory activities were also measured. The results indicate that the presence of a methylenedioxy ring attached at carbon (C)7-C8 is important for reducing the secretion of TNF- $\alpha$. Interestingly, this effect did not show a simple dependence on concentration. The selected alkaloids showed little or no anti-COX activity. The results obtained from the present experiments may provide additional information useful in understanding the structure-to-activity relationship of the quaternary benzophenanthridine alkaloids. The antiinflammatory potential and the cytotoxic effect are driven by the presence of a methylenedioxy ring attached at $\mathrm{C} 7-\mathrm{C} 8$ and $\mathrm{C} 2-\mathrm{C} 3$, respectively.
\end{abstract}

Cyclooxygenase, cytotoxicity, inflammation, $T N F-\alpha$

Plants and their products have been used since the beginning of human history as remedies for various diseases and disorders. During the $20^{\text {th }}$ century, the natural origin was in most cases replaced by synthetic drugs. Nowadays, we can see a reversing trend; natural medicine reappears in many areas of medicine (Perczel et al. 2016) and some of the used nature-originated drugs belong to alkaloids (e.g., galanthamine, paclitaxel). However, the usage of pure alkaloids has a longer history, e.g. in the case of morphine, codeine, etc. (Atanasov et al. 2015).

Quaternary benzophenanthridine alkaloids (QBAs) are known to have a wide range of biological activities, including antimicrobial, antifungal, anti-inflammatory, and antitumour activities (Walterova et al. 1995). The richest sources of these alkaloids are considered to be Sanguinaria canadensis L., Dicranostigma lactucoides Hook F. et Thomas, Chelidonium majus L., Macleaya cordata (Willd.) R.Br, Macleaya microcarpa (Maxim.) Fedde, Stylophorum lasiocarpum (Oliv.) Fedde, and a few species of the genus Bocconia. All of these species belong to the family Papaveraceae (Dostal and Potacek 1990). Extracts obtained from these plants, especially $M$. cordata and $S$. canadensis, have been used in traditional medicine for their anti-inflammatory effects, particularly against plaque build-up and gingivitis (Šimánek et al. 2003). Varying amounts of the major alkaloids

Address for correspondence:

Jan Hošek

Department of Molecular Biology and Pharmaceutical Biotechnology

Faculty of Pharmacy, University of Veterinary and Pharmaceutical Sciences Brno

Palackého tř. 1946/1, 61242 Brno

Phone: +420541562 852

Fax: +420 541219751

E-mail: hosekj@vfu.cz

http://actavet.vfu.cz/ 
sanguinarine and chelerythrine and the minor ones chelirubine, sanguirubine, chelilutine, sanguilutine, and macarpine have been found in these plants (Suchomelova et al. 2007; Šimánek et al. 2003; Slaninova et al. 2014; Sebrlova et al. 2015).

The biological effects of sanguinarine and chelerythrine have been studied extensively as they are commercially available. The potential of the minor alkaloids has not been fully revealed because their limited availability is a major challenge still to be overcome. However, a few uncommon properties and effects have been found. For instance, whereas sanguilutine and chelilutine exhibit antiproliferative and anti-microtubular activities (Slaninova et al. 2001), sanguirubine, chelirubine, and macarpine are antiproliferative and pro-apoptotic, as has been well documented (Slaninova et al. 2007). Macarpine and sanguirubine show a considerable fluorescence shift when bound to deoxyribonucleic acid (DNA), a property which makes them useful as fluorescent probes (Urbanova et al. 2009). Macarpine seems to be a promising novel cell-permeant DNA dye for livecell imaging and flow cytometry sorting (Slaninova et al. 2016). Sanguilutine has been found to preferentially induce necroptosis over apoptosis in melanoma cells (Hammerova et al. 2012).

Although all of the chosen alkaloids have been shown to possess anti-inflammatory properties and can be used to treat various inflammatory diseases, the mechanism of the anti-inflammatory activity of the minor alkaloids has yet to be described, and only a few studies have described the effects of sanguinarine and chelerythrine. Sanguinarine was found to block tumour necrosis factor-alpha (TNF- $\alpha)$-induced phosphorylation and the degradation of $\mathrm{I} \kappa \mathrm{B} \alpha$, an inhibitory protein of nuclear factor (NF)- $\kappa \mathrm{B}$, as well as inhibiting the translocation of the p65 subunit to a nucleus (Chaturvedi et al. 1997). Other experiments have shown that sanguinarine and chelerythrine are capable of binding to a glucocorticoid receptor and inducing its nuclear translocation, but they lack the capacity to turn on the transcriptional activity of this receptor (Dvorak et al. 2006). The inhibition of two important enzymes, 5- and 12-lipoxygenase, has also been described (Vavreckova et al. 1996). Niu et al. (2012) described significant anti-inflammatory effects of sanguinarine both in vitro, in lipopolysaccharide (LPS)-stimulated peritoneal macrophages, and in vivo, in acute and chronic inflammatory models. Sanguinarine also attenuated pulmonary histological changes and lung oedema in mice, and reduced the myeloperoxidase activity after LPS stimulation and the neutrophil infiltration in the lung. An immunohistochemical analysis showed that the expression of cyclooxygenase (COX)-2 was significantly suppressed in vivo in mice without affecting the inhibition of COX-1 ( $\mathrm{Li}$ et al. 2014b). The protective effect of chelerythrine on an ethanol-induced gastric ulcer in mice has been described recently ( $\mathrm{Li}$ et al. 2014a). It significantly reduced the gastric ulcer index, myeloperoxidase activities, and macroscopic and histological score in a dose-dependent manner.

As has been shown, sanguinarine and chelerythrine have interesting anti-inflammatory properties, but nothing is known about the anti-inflammatory activity of other, less common, QBAs. The aim of this paper is to evaluate the anti-inflammatory potential of five minor QBAs sanguilutine (3), sanguirubine (4), chelirubine (5), chelilutine (6), and macarpine (7) in vitro and to compare them with the extensively studied sanguinarine (1) and chelerythrine (2) (Fig. 1).

\section{Materials and Methods}

Isolation and identification of the selected alkaloids

The benzophenanthridine alkaloids were isolated in the laboratories of the Department of Biochemistry (Faculty of Medicine, Masaryk University) from the plant material of Macleaya microcarpa (Maxim.) Fedde, Dicranostigma lactucoides Hook. F. et Thomson, Sanguinaria canadensis L., and Stylophorum lasiocarpum (Oliv.) Fedde as was described previously (Táborská et al. 1978; Dostal et al. 1992). The alkaloids were at least $98 \%$ pure according to high-performance liquid chromatography (HPLC) analysis (Suchomelova et al. 2007). 
<smiles></smiles>

Sanguinarine (1)<smiles>COc1cc2ccc3c4c(OC)cc5c(c4c[n+](C)c3c2cc1OC)OCO5</smiles>

Sanguirubine (4)<smiles>COc1cc2c3c(OC)cc4c(c3c[n+](C)c2c2cc3c(cc12)OCO3)OCO4</smiles>

Macarpine (7)<smiles>COc1cc2ccc3c4c(OC)cc(OC)c(O[As])c4c[n+](C)c3c2cc1OC</smiles><smiles></smiles>

Chelirubine (5)<smiles>COc1cc(OC)c2c(c[n+](C)c3c4cc5c(cc4ccc23)OCO5)c1OC</smiles>

Chelilutine (6)

Fig.1. Structures of tested QBAs 1-7.

\section{Maintenance and preparation of macrophages}

The THP-1 human monocytic leukaemia cell line was obtained from the European Collection of Authenticated Cell Cultures (ECACC, Salisbury, UK). The cells were cultivated at $37^{\circ} \mathrm{C}$ in RPMI 1640 medium supplemented with $2 \mathrm{mM} \mathrm{L}$-glutamine (Biosera, Boussens, France), 10\% foetal bovine serum (FBS) (HyClone, GE Healthcare, Logan, UT, USA), $100 \mathrm{U} / \mathrm{ml}$ penicillin, and $100 \mu \mathrm{g} / \mathrm{ml}$ streptomycin (Biosera, Boussens, France) in a humidified atmosphere containing $5 \% \mathrm{CO}_{2}$. The culture was split twice a week when cells had reached a concentration of $5-7 \times 10^{5} \mathrm{cells} / \mathrm{ml}$. The cell number and viability for routine passaging were determined following staining with erythrosin B (Sigma-Aldrich, Steinheim, Germany). Cells were counted manually using a haemocytometer and a light microscope. Stabilized cells $\left(5^{\text {th }}-20^{\text {th }}\right.$ passage) were split into multiwell plates to achieve a concentration of $5 \times 10^{5} \mathrm{cells} / \mathrm{ml}$, and differentiation into macrophages was induced by phorbol myristate acetate (PMA) (SigmaAldrich), as described previously by Pencikova et al. (2012).

\section{Cytotoxicity testing}

THP-1 cells (floating monocytes, $5 \times 10^{5}$ cells $/ \mathrm{ml}$ ) were incubated with $100 \mu \mathrm{l}$ of a serum-free RPMI 1640 medium, which does not support the cell proliferation, and seeded into 96-well plates in triplicate at $37^{\circ} \mathrm{C}$. Measurements were taken $24 \mathrm{~h}$ after treatment with increasing concentrations $(0.04-10 \mu \mathrm{M})$ of the test alkaloids 3-7 dissolved in dimethylsulphoxide (DMSO). The viability of cells after compounds application was measured by the Cell Proliferation Reagent WST-1 (Roche, Basel, Switzerland), according to the manufacturer's manual. The amount of formazan created (which corresponds to the number of metabolically active cells in the culture) was calculated as a percentage of the control cells, which were treated only with DMSO and were assigned as $100 \%$. The cytotoxicity of sanguinarine (1) and chelerythrine (2) has been measured previously (Pencikova et al. 2012).

\section{Evaluation of cytokine secretion}

Differentiated macrophages (500 $000 \mathrm{cells} / \mathrm{ml}$ ) were pre-treated for $1 \mathrm{~h}$ with solutions of the test compounds $(20-500 \mathrm{nM})$ or prednisone $(1 \mu \mathrm{M})$ dissolved in DMSO or with DMSO alone (the final DMSO concentration was $0.1 \%$ in all wells); the concentrations of the test compounds used lack of cytotoxic effects (cell viability $>94 \%$ ). The inflammatory-like response was triggered by adding $1 \mu \mathrm{g} / \mathrm{ml}$ lipopolysaccharide isolated from Escherichia coli 0111:B4 (Sigma-Aldrich) and dissolved in water to the pre-treated macrophages; the control cells were left without LPS treatment. Macrophages were incubated with LPS for the next $24 \mathrm{~h}$. After this period, the medium was collected and the concentration of TNF- $\alpha$ was measured using an instant enzyme-linked immunosorbent assay (ELISA) kit (eBioscience, San Diego, CA, USA), according to the manufacturer's manual. Each experiment was run in triplicate. 
Detection of cyclooxygenase inhibition

The inhibitory potential of the seven alkaloids tested was determined by the cell-free model by using a COX colorimetric inhibitor screening assay kit (Cayman Chemical Co.,Ann Arbor, MI, USA), which measures the peroxidase component of COXs. The kit includes both ovine COX-1 and human recombinant COX-2 enzymes in order to screen isoenzyme-specific inhibitors. The peroxidase activity is assayed colorimetrically by monitoring the appearance of oxidized N,N,N',N'-tetramethyl- $p$-phenylenediamine at $590 \mathrm{~nm}$. The COX-1 and COX-2 tests were performed in two independent experiments with three replicates. At least four concentrations were used to calculate the $\mathrm{IC}_{50}$ values of the tested compounds. All of the samples were dissolved in DMSO.

\section{Statistical analysis}

All experiments were performed in a triplicate, and results are presented as mean values, with error bars representing the standard error (SE) of the mean. GraphPad Prism 6.01 (GraphPad Software Inc., San Diego, CA, USA) was used to perform the analysis.

The $\mathrm{IC}_{50}$ values were calculated from the curve fitting using four parameters logistic (4PL) regression. A one-way ANOVA test followed by a Tukey's post hoc test for multiple comparisons was used for statistical analysis of TNF- $\alpha$ secretion. A value of $P<0.05$ was considered to be significant.

Table 1 . Cell viability expressed as $\mathrm{IC}_{50}$ values of compounds 1-7 obtained for the THP-1 cell line.

\begin{tabular}{lcc}
\hline & $\mathrm{IC}_{50}$ & $95 \% \mathrm{CI}$ \\
\hline Sanguinarine (1) & $0.8 \mu \mathrm{M} *$ & n.d. \\
Chelerythrine (2) & $3.5 \mu \mathrm{M} *$ & n.d. \\
Sanguilutine (3) & $5.6 \pm 1.3 \mu \mathrm{M}$ & $3.5-9.1 \mu \mathrm{M}$ \\
Sanguirubine (4) & $5.8 \pm 1.3 \mu \mathrm{M}$ & $3.5-9.9 \mu \mathrm{M}$ \\
Chelirubine (5) & $0.4 \pm 1.2 \mu \mathrm{M}$ & $0.3-0.6 \mu \mathrm{M}$ \\
Chelilutine (6) & $1.7 \pm 1.5 \mu \mathrm{M}$ & $0.8-4.0 \mu \mathrm{M}$ \\
Macarpine (7) & $0.9 \pm 1.1 \mu \mathrm{M}$ & $0.7-1.1 \mu \mathrm{M}$ \\
\hline
\end{tabular}

*Data were published previously (Pencikova et al. 2012). $\mathrm{IC}_{50}$ - the half maximal inhibitory concentration; $95 \% \mathrm{CI}-$ $95 \%$ confidence interval; n.d. - not determined.

$\left(\mathrm{IC}_{50}=5.6 \mu \mathrm{M}\right.$ and $5.8 \mu \mathrm{M}$, respectively) (Fig. 2). Based on the results of the cytotoxicity evaluation, the concentration of $100 \mathrm{nM}$ was selected as non-toxic for further in vitro tests.

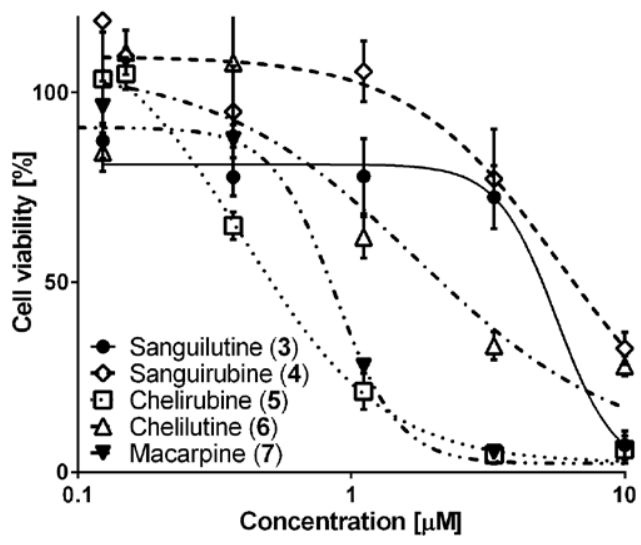

Fig. 2. Dose-dependent cytotoxicity of compounds 3-7.

\section{Results}

Before making cell-based assays, the cytotoxicity of the alkaloids 3-7 was evaluated [alkaloids $\mathbf{1}$ and $\mathbf{2}$ had been measured previously (Pencikova et al. 2012)] (Table1). All of the selected alkaloids showed $\mathrm{IC}_{50}$ (half maximal inhibitory concentration) values in the range of $0.4-5.8 \mu \mathrm{M}$. Chelirubine (5), sanguinarine (1), and macarpine (7) were noted as the most cytotoxic compounds $\left(\mathrm{IC}_{50}<1 \mu \mathrm{M}\right)$. Less cytotoxic were alkaloids $\mathbf{2}$ and $\mathbf{6}$, with the $\mathrm{IC}_{50}$ values of $3.5 \mu \mathrm{M}$ and $1.7 \mu \mathrm{M}$, respectively. The lowest cytotoxicity was observed for alkaloids $\mathbf{3}$ and $\mathbf{4}$
To evaluate the anti-inflammatory potential of the minor QBAs, the human macrophage-like cell line THP-1 was selected as a model of the inflammatory response in vitro. Cells pre-treated with the selected alkaloids were stimulated by bacterial lipopolysaccharide, and the production of the pro-inflammatory cytokine TNF- $\alpha$ was measured. A noticeable but not significant reduction in the secretion of TNF- $\alpha$ was observed for alkaloids 1, 4, and 7; compounds 2, 3, 5, and $\mathbf{6}$ had no effect (Fig. 3a). Because compounds $\mathbf{1}$ and $\mathbf{4}$ showed the greatest ability to reduce the secretion of TNF- $\alpha$ at a concentration of $100 \mathrm{nM}$, they were 

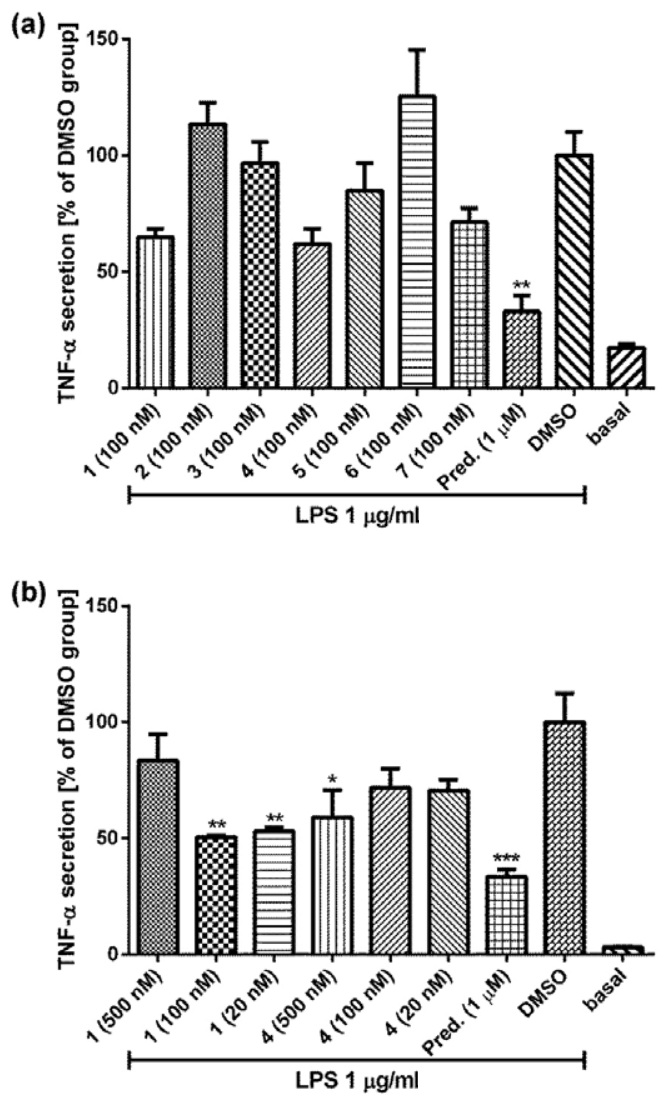

Fig. 3. The effect of QBAs 1-7 (a), and 1 and 4 (b) on the secretion of TNF- $\alpha$. THP-1 macrophages were pretreated with compounds 1-7 and prednisone (Pred.) at the indicated concentrations or with DMSO only (DMSO and basal) for $1 \mathrm{~h}$. Subsequently, LPS $(1 \mu \mathrm{g} / \mathrm{ml})$ was added [except for the control cells (basal)] to trigger the secretion of the pro-inflammatory cytokine TNF- $\alpha$. After $24 \mathrm{~h}$, the amount of TNF- $\alpha$ was evaluated by ELISA. The results are expressed as the mean \pm S.E. for three independent experiments.

*Indicates a significant difference in comparison with the DMSO-treated cells $P<0.05$, ** indicates a significant difference in comparison with the DMSO -treated cells $P<0.01$, and *** indicates a significant difference in comparison with the DMSO-treated cells $P<0.001$. DMSO - dimethylsulphoxide; ELISA - enzyme-linked immunosorbent assay; LPS - lipopolysaccharide; TNF- $\alpha$ - tumour necrosis factor $\alpha$.

selected to evaluate the dependence of this effect on concentration $(500,100$, and $20 \mathrm{nM})$ (Fig. 3b]. The greatest inhibition effect was observed at the concentration of $500 \mathrm{nM}$, lower for concentrations of 100 and $20 \mathrm{nM}$ of $\mathbf{4}$, where the effect was comparable. The same profile for the expression was observed for compound 1 at concentrations of 100 and $20 \mathrm{nM}$, but at the highest concentration $(500 \mathrm{nM})$, sanguinarine (1) displayed a lower activity than for 100 and $20 \mathrm{nM}$.

The potential for directly modulating the activities of COX-1 and COX-2 was also examined in this paper. Macarpine (7) showed a considerable ability to inhibit COX-2 with an $\mathrm{IC}_{50}$ value of $148 \mu \mathrm{M}$. The results demonstrated that macarpine (7) preferentially inhibited COX-2 rather than COX-1. Other compounds were inactive or showed a nonsignificant inhibitory potential at a concentration of $150 \mu \mathrm{M}$, with the efficiencies presented in Table 2. 
Table 2. $\mathrm{IC}_{50}$ values of compounds 1-7 obtained for COX-1 and COX-2 inhibition.

\begin{tabular}{|c|c|c|c|c|c|}
\hline \multirow{2}{*}{\multicolumn{2}{|c|}{ Concentration $[\mu \mathrm{M}]$}} & \multicolumn{2}{|c|}{$\%$ of inhibition } & \multicolumn{2}{|c|}{$\mathrm{IC}_{50}[\mu \mathrm{M}]$} \\
\hline & & COX-1 & $\mathrm{COX}-2$ & COX-1 & $\mathrm{COX}-2$ \\
\hline \multirow[t]{2}{*}{ Sanguinarine (1) } & 450 & 47.4 & 84.9 & $>450307.4$ & \\
\hline & 150 & 8.0 & 11.5 & & \\
\hline \multirow[t]{3}{*}{ Chelerythrine (2) } & 450 & 58.6 & 16.6 & $362.4 \pm 2.4$ & $>450$ \\
\hline & 150 & 43.7 & 0 & & \\
\hline & 45 & 18.9 & 0 & & \\
\hline \multirow[t]{2}{*}{ Sanguilutine (3) } & 450 & 49.3 & 33.2 & $>450$ & $>450$ \\
\hline & 150 & 3.4 & 46.0 & & \\
\hline \multirow[t]{2}{*}{ Sanguirubine (4) } & 450 & 14.8 & 0 & $>450$ & $>450$ \\
\hline & 150 & 15.9 & 1.0 & & \\
\hline \multirow[t]{2}{*}{ Chelirubine (5) } & 450 & 29.2 & 3.9 & $>450$ & $>450$ \\
\hline & 150 & 1.8 & 0 & & \\
\hline \multirow[t]{3}{*}{ Chelilutine (6) } & 450 & 56.2 & 49.8 & $399.7 \pm 2.5$ & $>450$ \\
\hline & 150 & 45.5 & 0 & & \\
\hline & 45 & 6.3 & 0 & & \\
\hline \multirow[t]{3}{*}{ Macarpine (7) } & 450 & 40.0 & 100 & $>450$ & $148.1 \pm 9.3$ \\
\hline & 150 & 33.8 & 50.8 & & \\
\hline & 45 & 0 & 6.5 & & \\
\hline Indomethacin & & & & $1.9 \pm 0.6 *$ & $2.5 \pm 0.9 *$ \\
\hline
\end{tabular}

*Data were published previously (Hošek et al. 2011). COX - cyclooxygenase; $\mathrm{IC}_{50}$ - the half maximal inhibitory concentration.

\section{Discussion}

QBAs possess significant cytotoxic activity. The type of substituent affects the structure and influences their cytotoxicity. Slaninova et al. (2001) observed reduced cytotoxicity in HeLa cells for QBAs with a lower number of methylenedioxy rings (Slaninova et al. 2001). Other studies in various cell lines led to an assumption that methylenedioxy groups attached at carbon (C)2-C3 and C7-C8 probably guarantee greater alkaloid toxicity (Slunska et al. 2010; Slaninova et al. 2007). These findings are in agreement with our results. The most cytotoxic compounds chelirubine (5), sanguinarine (1), and macarpine (7) contain methylenedioxy rings attached at C2-C3 and C7-C8. Less cytotoxic were compounds 2 and $\mathbf{6}$, with the $\mathrm{IC}_{50}>2 \mu \mathrm{M}$. These alkaloids each have a single methylenedioxy ring attached at $\mathrm{C} 2-\mathrm{C} 3$, with methoxy groups at $\mathrm{C} 7$ and $\mathrm{C} 8$. The lowest cytotoxicity was observed for compounds 3 and $4\left(\mathrm{IC}_{50}>5.5 \mu \mathrm{M}\right)$. These molecules include either a single methylenedioxy ring attached at C7-C8 (4) or none at all (3). These findings support the assumption that a methylenedioxy ring attached at $\mathrm{C} 2-\mathrm{C} 3$ may be crucial for the cytotoxic effect of QBAs.

Previous studies have indicated a promising anti-inflammatory effect for sanguinarine (1) and chelerythrine (2) both in vitro and in vivo (Niu et al. 2011; Niu et al. 2012; Pencikova et al. 2012). The results obtained in this study indicate that the presence of a methylenedioxy ring attached at C7-C8 is important for reducing the secretion of TNF- $\alpha$. The only exception is compound $\mathbf{5}$, which possesses a methylenedioxy ring attached at C7-C8 but only minutely diminished the expression of this cytokine. Furthermore, the presence of a single methylenedioxy ring attached at $\mathrm{C} 2-\mathrm{C} 3$, but not at $\mathrm{C} 7-\mathrm{C} 8$, rather increased the production of TNF- $\alpha$ (compounds 2 and 6). Compounds $\mathbf{1}$ and $\mathbf{4}$ showed 
the greatest ability to reduce the secretion of TNF- $\alpha$ and they were selected to evaluate the dependence of this effect on concentration. Interestingly, at the highest concentration $(500 \mathrm{nM})$, sanguinarine (1) displayed a lower activity than for 100 and $20 \mathrm{nM}$. This could be ascribed to the greater cytotoxic effect of compound $\mathbf{1}$, which could have led to the loss of the antiphlogistic potential in the sub-toxic concentration. However, this effect was not observed in murine primary macrophages (Niu et al. 2012). It could be explained by the varying sensitivity of different cell lines to the alkaloids, as described previously (Malikova et al. 2006).

Previous papers have shown the ability of some benzophenanthridine alkaloids to inhibit the production of the prostaglandin $\mathrm{PGE}_{2}$ by inhibiting the expression of COX-2 (Niu et al. 2011; Li et al. 2014b). However, except for macarpine (7), other test compounds were inactive or showed an insignificant inhibitory potential on COXs. These findings together with previously published results indicate that these alkaloids act by inhibiting the expression of COXs rather by their directly inactivating them.

The results obtained from the presented experiments contribute to our understanding of the structure-to-activity relationship of QBAs. The anti-inflammatory potential and the cytotoxic effect are driven by the presence of methylenedioxy rings attached at C7-C8 and $\mathrm{C} 2-\mathrm{C} 3$, respectively. Combining the presence or absence of such rings may enable a search for compounds with cytotoxic activity (potential anti-cancer drugs), with antiphlogistic effects (potential anti-inflammatory drugs), or with both of these features.

\section{Acknowledgement}

We acknowledge Dr. Frank Thomas Campbell for his critical reading of this manuscript.

Financial support of this work by IGA VFU No. 54/2014/FaF (to P.H.) and Specific University Research Grant No. MUNI/A/1205/2016 is gratefully acknowledged.

Dedicated to Professor Václav Suchý on the occasion of his $80^{\text {th }}$ birthday.

\section{Declaration of Interest}

The authors declare no conflict of interest.

\section{References}

Atanasov AG, Waltenberger B, Pferschy-Wenzig EM, Linder T, Wawrosch C, Uhrin P, Temml V, Wang L, Schwaiger S, Heiss EH, Rollinger JM, Schuster D, Breuss JM, Bochkov V, Mihovilovic MD, Kopp B, Bauer R, Dirsch VM, Stuppner H 2015: Discovery and resupply of pharmacologically active plant-derived natural products: A review. Biotechnol Adv 33: 1582-1614

Dostal J, Potacek M 1990: Quaternary benzo[C]phenanthridine alkaloids. Collect Czech Chem C 55: 2840-2873

Dostal J, Taborska E, Slavik J 1992: Preparative column chromatography of quaternary benzophenanthridine alkaloids of Dicranostigma lactucoides. Fitoterapia 63: 67-69

Dvorak Z, Vrzal R, Maurel P, Ulrichova J 2006: Differential effects of selected natural compounds with antiinflammatory activity on the glucocorticoid receptor and NF-kappaB in HeLa cells. Chem-Biol Interact 159: 117-128

Hammerova J, Uldrijan S, Taborska E, Vaculova AH, Slaninova I 2012: Necroptosis modulated by autophagy is a predominant form of melanoma cell death induced by sanguilutine. Biol Chem 393: 647-658

Hošek J, Bartoš M, Chudík S, Dall'Acqua S, Innocenti G, Kartal M, Kokoška L, Kollár P, Kutil Z, Landa P, Marek R, Závalová V, Žemlicka M, Śmejkal K 2011: Natural compound cudraflavone B shows promising anti-inflammatory properties in vitro. J Nat Prod 74: 614-619

Chaturvedi MM, Kumar A, Darnay BG, Chainy GBN, Agarwal S, Aggarwal BB 1997: Sanguinarine (pseudochelerythrine) is a potent inhibitor of NP-kappa B activation, I kappa B alpha phosphorylation, and degradation. J Biol Chem 272: 30129-30134

Li WF, Hao DJ, Fan T, Huang HM, Yao H, Niu XF 2014a: Protective effect of chelerythrine against ethanolinduced gastric ulcer in mice. Chem-Biol Interact 208: 18-27

Li WF, Li HN, Mu QL, Zhang HL, Yao H, Li JS, Niu XF 2014b: Protective effect of sanguinarine on LPS-induced endotoxic shock in mice and its effect on LPS-induced COX-2 expression and COX-2 associated PGE(2) release from peritoneal macrophages. Int Immunopharmacol 22: 311-317 
Malikova J, Zdarilova A, Hlobilkova A, Ulrichova J 2006: The effect of chelerythrine on cell growth, apoptosis, and cell cycle in human normal and cancer cells in comparison with sanguinarine. Cell Biol Toxicol 22: 439453

Niu XF, Fan T, Li WF, Xing W, Huang HM 2012: The anti-inflammatory effects of sanguinarine and its modulation of inflammatory mediators from peritoneal macrophages. Eur J Pharmacol 689: 262-269

Niu XF, Zhou P, Li WF, Xu HB 2011: Effects of chelerythrine, a specific inhibitor of cyclooxygenase-2, on acute inflammation in mice. Fitoterapia 82: 620-625

Pencikova K, Kollar P, Zavalova VM, Taborska E, Urbanova J, Hosek J 2012: Investigation of sanguinarine and chelerythrine effects on LPS-induced inflammatory gene expression in THP-1 cell line. Phytomedicine 19: 890-895

Perczel A, Atanasov AG, Sklenar V, Novacek J, Papouskova V, Kaderavek P, Zidek L, Kozlowski H, Watly J, Hecel A, Kolkowska P, Koca J, Svobodova-Varekova R, Pravda L, Sehnal D, Horsky V, Geidl S, Enriz RD, Matejka P, Jenistova A, Dendisova M, Kokaislova A, Weissig V, Olsen M, Coffey A, Ajuebor J, Keary R, SanzGaitero M, van Raaij MJ, McAuliffe O, Waltenberger B, Mocan A, Smejkal K, Heiss EH, Diederich M, Musiol R, Kosmrlj J, Polanski J, Jampilek J 2016: The Eighth Central European Conference "Chemistry towards Biology": Snapshot. Molecules 21: 1381

Sebrlova K, Pes O, Slaninova I, Vymazal O, Kantorova J, Taborska E 2015: Seasonal variation in alkaloid composition and antiproliferative activity of Stylophorum lasiocarpum (Oliv.) Fedde. Chem Pap 69: 698-708

Slaninova I, Lopez-Sanchez N, Sebrlova K, Vymazal O, Frade JM, Taborska E 2016: Introduction of macarpine as a novel cell-permeant DNA dye for live cell imaging and flow cytometry sorting. Biol Cell 108: 1-18

Slaninova I, Pencikova K, Urbanova J, Slanina J, Taborska E 2014: Antitumour activities of sanguinarine and related alkaloids. Phytochem Rev 13: 51-68

Slaninova I, Slunska Z, Sinkora J, Vlkova M, Taborska E 2007: Screening of minor benzo(c)phenanthridine alkaloids for antiproliferative and apoptotic activities. Pharm Biol 45: 131-139

Slaninova I, Taborska E, Bochorakova H, Slanina J 2001: Interaction of benzo[c]phenanthridine and protoberberine alkaloids with animal and yeast cells. Cell Biol Toxicol 17: 51-63

Slunska Z, Gelnarova E, Hammerova J, Taborska E, Slaninova I 2010: Effect of quaternary benzo[c]phenanthridine alkaloids sanguilutine and chelilutine on normal and cancer cells. Toxicol In Vitro 24: 697-706

Suchomelova J, Bochorakova H, Paulova H, Musil P, Taborska E 2007: HPLC quantification of seven quaternary benzo[c]phenanthridine alkaloids in six species of the family Papaveraceae. J Pharm Biomed Anal 44: 283-287

Šimánek V, Vespalec R, Šedo A, Ulrichová J, Vičar J 2003: Quaternary benzo[C]phenanthridine alkaloids biological activities. In: Schneider M (Ed.):Chemical Probes in Biology. Springer Netherlands; pp. 245-254

Táborská E, Věžník F, Slavíková L, Slavík J 1978: Quaternary alkaloids of three species of Dicranostigma HOOK. f. et THOMS. Collect Czech Chem Commun 43: 1108-1112

Urbanova J, Lubal P, Slaninova I, Taborska E, Taborsky P 2009: Fluorescence properties of selected benzo[c] phenantridine alkaloids and studies of their interaction with CT DNA. Anal Bioanal Chem 394: 997-1002

Vavreckova C, Gawlik I, Muller K 1996: Benzophenanthridine alkaloids of Chelidonium majus; I. Inhibition of 5- and 12-lipoxygenase by a non-redox mechanism. Planta Med 62: 397-401

Walterova D, Ulrichova J, Valka I, Vicar J, Vavreckova C, Taborska E, Harjrader RJ, Meyer DL, Cerna H, Simanek V 1995: Benzo[c]phenanthridine alkaloids sanguinarine and chelerythrine: biological activities and dental care applications. Acta Univ Palacki Olomouc Fac Med 139: 7-16 